\title{
Ефективність застосування регіонарного модифікованого клаптя великого грудного м'яза та вільного променевого клаптя передпліччя для заміщення субтотальних дефектів язика в онкологічних хворих
}

\author{
О. В. Кравець ${ }^{1}$, А. В. Копчак ${ }^{2}$, О. В. Хлинін ${ }^{1}$, О. В. Буртин ${ }^{1}$, В. Г. Гур'янов ${ }^{2}$ \\ ${ }^{1}$ Національний інститут раку, м. Київ, \\ ${ }^{2}$ Національний медичний університет імені О. О. Богомольця, м. Київ

\section{Efficacy of application of regional modified flap of major thoracic muscle versus free radial flap of a forearm for substitution of subtotal defects of a tongue in oncological patients}

\author{
O. V. Kravets ${ }^{1}$, A. V. Kopchak ${ }^{2}$, O. V. Khlynin ${ }^{1}$, O. V. Burtyn ${ }^{1}$, V. G. Hurianov ${ }^{2}$ \\ ${ }^{1}$ National Cancer Institute, Kyiv, \\ ${ }^{2}$ Bogomolets National Medical University, Kyiv
}

\section{Реферат}

Мета. Порівняти ефективність застосування регіонарного модифікованого клаптя великого грудного м'яза (РМКВГМ) та вільного променевого клаптя передпліччя (ВПКП) для пластичного заміщення субтотальних дефектів язика.

Матеріали і методи. До дослідження включено 69 пацієнтів з раком язика III - IV стадій. Хворих розподілили на дві групи в залежності від виду реконструктивної методики. Основну групу склав 31 пацієнт, якому для усунення дефекту язика використали ВПКП, порівняльну - 38 хворих, яким для усунення дефектів язика використали РМКВГМ. Результати. Середня тривалість операції у пацієнтів основної групи становила $(9,91 \pm 0,21)$ год, у пацієнтів порівняльної групи - $(6,03 \pm 0,19)$ год ( $<0,001)$, середня тривалість стаціонарного лікування - відповідно $(15,8 \pm 1,3)$ та $(14,5 \pm$ $1,5)$ діб $(\mathrm{p}=0,002)$. Статистично значущих відмінностей за частотою виникнення ускладнень після пересадки клаптів $(\mathrm{p}=0,81)$, післяопераційних ускладнень $(\mathrm{p}=0,49)$, функціональним статусом $(\mathrm{p}>0,05)$ та якістю життя $(\mathrm{p}>0,05)$ між групами не виявлено.

Висновки. У разі застосування РМКВГМ для заміщення субтотальних дефектів язика у порівнянні із застосуванням ВПКП достовірно скорочується тривалість оперативного втручання та стаціонарного лікування, а показники функціональної реабілітації і якості життя хворих порівнянні.

Ключові слова: субтотальний дефект язика; вільний променевий клапоть передпліччя; регіонарний модифікований клапоть великого грудного м'яза.

Abstract

Objective. To compare the efficacy of application of a regional modified flap of major thoracic muscle (RMFMTHM) and a free radial flap of a forearm (FRFF) for plastic substitution of subtotal defects of a tongue.

Materials and methods. There were 69 patients, suffering the tongue cancer Stages III - IV, included into investigation. The patients were distributed into two groups, depending on the kind of reconstructive procedure applied. The main group have consisted of 31 patients, in whom FRFF was applied for the tongue defects correction, and a comparison one, 38 patients, in whom RMFMTHM was used for correction of the tongue defects.

Results. Average duration of operation in patients of the main group have constituted $(9.91 \pm 0.21)$ hours, while in patients of the comparison group - $(6.03 \pm 0.19)$ yr $(\mathrm{p}<0.001)$, average period of stationary treatment - accordingly, $-(15.8 \pm 1.3)$ and $(14.5 \pm 1.5)$ days $(p=0.002)$. Statistically significant differences in indices of the morbidity occurrence rate after the flaps transplantation $(p=0.81)$, postoperative complications $(p=0.49)$, functional status $(p>0.05)$ and quality of life $(p>0.05)$ between the groups was not revealed.

Conclusion. While application of RMFMTHM for substitution of the tongue subtotal defects, comparing with application of FRFF, the operative intervention and the stationary stay duration trustworthily shortens, and the indices of functional rehabilitation and the quality of life in patients are comparable.

Keywords: subtotal defect of a tongue; free radial flap of a forearm; regional modified flap of a major thoracic muscle

Лікування хворих з місцево-поширеним раком язика передбачає хірургічне втручання з наступною променевою або одночасною хіміопроменевою терапією [1]. Субтотальна резекція язика призводить до суттєвого порушення функцій мовлення та ковтання. Функціональний результат реконструкції залежить від збереження рухо- мості кореня язика та відновлення об'єму «неоязика». Цілісність під'язикового нерва та іннервація кореня язика мають важливе значення для забезпечення глоткової фази ковтання і захисту верхніх дихальних шляхів. У разі порушення рухомості кореня язика зростає ризик аспірації. Іншим важливим фактором, який впливає на функ- 
ціональний результат, є відновлення анатомічної форми та об'єму «неоязика». Рухомість та контакт реконструйованого язика з твердим піднебінням є визначальними у відновленні функції мовлення [2, 3].

Для пластичного заміщення субтотальних дефектів язика використовують вільні (променевий передпліччя, передньо-латеральний стегна) та регіонарний (великого грудного м'яза) клапті. Відомо про добрі функціональні результати усунення субтотальних дефектів язика як вільним променевим клаптем передпліччя (ВПКП), так і передньо-латеральним клаптем стегна, а щодо застосування регіонарного клаптя великого грудного м'яза досі точаться дискусії. Недоліками клаптя великого грудного м'яза, які перешкоджають його широкому використанню, вважають обмежену дугу ротації, прив'язку реконструйованого язика до м'язової ніжки клаптя та деформацію донорської ділянки [4 - 6].

В останні роки зросла роль регіонарних клаптів як альтернативи вільним клаптям у разі пластичного заміщення дефектів ротової порожнини, що пов'язано з розробленням нових модифікацій, позбавлених недоліків стандартних регіонарних клаптів [7, 8]. Зокрема, запропоновано удосконалене виділення клаптя великого грудного м'яза, спрямоване на збільшення дуги його ротації, мобільності та мінімізацію ускладнень у донорській ділянці [9]. Дотепер немає досліджень, у яких порівняно ефективність застосування регіонарного модифікованого клаптя великого грудного м'яза (РМКВГМ) та ВПКП або передньо-латерального клаптя стегна для заміщення субтотальних дефектів язика. Більшість дослідників, порівнюючи різні види клаптів, оцінювали всі дефекти ротової порожнини або язика в цілому, а не конкретний дефект, через що немає можливості визначити переваги тієї чи іншої реконструктивної методики [10]. Крім того, як правило, порівнювали тривалість операції, приживлення клаптів, післяопераційні ускладнення, ускладнення в донорській ділянці, собівартість лікування, а порівняльних даних щодо функціонального статусу та особливо якості життя пацієнтів вкрай мало.

Мета дослідження: порівняти ефективність застосування РМКВГМ та ВПКП для пластичного заміщення субтотальних дефектів язика.

\section{Матеріали і методи дослідження}

Проведено ретроспективний порівняльний аналіз результатів оперативних втручань, виконаних 69 пацієнтам з раком язика, що перебували на лікуванні у відділенні пухлин голови та шиї Національного інституту раку з 2012 по 2016 р. Чоловіків було 60 (87,0\%), жінок - 9 (13,0\%) у віці від 30 до 76 років. Середній вік хворих становив $(55,9 \pm 9,1)$ року. Плоскоклітинний рак різного ступеня диференціювання діагностовано у 69 (100\%) пацієнтів. За поширеністю процесу III стадію (Т3N0-1M0) діагностовано у 28 (40,6\%) пацієнтів, IV (T3N2M0, T1N1-3M0) - у 41 (59,4\%) пацієнта.

Усім пацієнтам проведене хірургічне лікування в об'ємі субтотальної резекції язика, білатеральної шийної лімфодисекції та реконструкції язика. Хворих розподілили на дві групи в залежності від виду реконструктивної мето- дики, застосованої для заміщення субтотального дефекту язика. Основну групу склав 31 пацієнт, якому для усунення дефекту язика використали ВПКП, порівняльну 38 хворих, яким для заміщення дефекту язика використали РМКВГМ. Групи порівнянні за віком, гендерними ознаками, видом дефекту язика, стадією захворювання (TNM), тяжкістю супутньої патології.

Критерії, за якими пацієнтів включали в дослідження: місцево-поширений рак язика без попередньо проведеного променевого або хіміопроменевого лікування; реконструктивне втручання на язику після його субтотальної резекції.

Критерії, за якими хворих не включали в дослідження: декомпенсована серцева недостатність; цукровий діабет 3 нестабільною гіперглікемією; найближчі три місяці після перенесеного інфаркту або інсульту; стан хворого, визначений як протипоказання до реконструктивної операції.

Виділяли ВПКП прямокутної форми за загальноприйнятою методикою. РМКВГМ виділяли в такий спосіб: шкірну частину клаптя окреслювали в проекції великого грудного м'яза каудально-медіально до сосково-ареолярного комплексу без включення шкіри над прямим м'язом живота; у склад клаптя включали третій міжреберний перфорант внутрішньої грудної артерії, який забезпечує кровопостачання дистальних відділів його шкірної частини; великий грудний м'яз пересікали горизонтально на рівні термінальних відділів грудо-надплечової артерії, зберігаючи ключичну та частково грудинно-реброву його частини; судинну «ніжку» виділяли селективно в тунелі під збереженим фрагментом великого грудного м'яза; в донорську ділянку клапоть проводили через сформований тунель над ключицею [9].

Порівнювали тривалість оперативного втручання, стаціонарного лікування, ускладнення після пересадки клаптів, післяопераційні ускладнення, функціональний статус та якість життя хворих. Функціональний статус вивчали за шкалою функціонування для хворих з раком голови та шиї PSS-HN (Performance Status Scale for Head and Neck Cancer Patients) через 6 та 12 міс після хірургічного лікування, оцінюючи повноцінність дієти, харчування на людях, зрозумілість мовлення. Якість життя оцінювали за опитувальником якості життя Вашингтонського університету UW-QOL v4 (University of Washington Quality of Life questionnaire, version 4) через 6 та 12 міс після хірургічного лікування.

Статистичний аналіз результатів дослідження проводили з використанням пакета MedCalc v. 18.11 (MedCalc Software bvba, Бельгія, 1993 - 2018 рр.). Для представлення кількісних ознак розраховували середнє значення показника ( $\mathrm{x})$ та його середньоквадратичне відхилення ( $\pm \mathrm{SD})$, якісних - частоту ознаки (\%). Кількісні ознаки порівнювали з використанням критерію Ст'юдента (у разі нормального закону розподілу) або критерію W-Вілкоксона (у разі закону розподілу, відмінного від нормального), розподіл на нормальність перевіряли за критерієм ШапіроВілка. Для порівняння якісних показників використовували критерій $\chi^{2}$ (з урахуванням поправки Йєйтса). Для оцінки клінічного ефекту розраховували його величину 
та 95\% вірогідний інтервал (95\% ВI). Критичним рівнем значущості вважали $\alpha_{\text {кр. }}=0,05$.

\section{Результати}

Реконструкцію язика виконували одномоментно з видаленням первинної пухлини та регіонарних лімфатичних вузлів. Усім 69 (100\%) хворим розпочали ад'ювантну променеву або хіміопроменеву терапію у строки до 6 тижнів після хірургічного етапу комплексного лікування.

Проаналізувавши тривалість оперативних втручань, ми визначили, що середня тривалість операції у пацієнтів основної групи становила $(9,91 \pm 0,21)$ год, у пацієнтів порівняльної групи - $(6,03 \pm 0,19)$ год $(\mathrm{p}<0,001)$. Застосування РМКВГМ у порівнянні з ВПКП для заміщення субтотальних дефектів язика скорочувало тривалість оперативного втручання в середньому на 3,9 год (95\% ВI 3,8 год - 4,0 год).

Встановлено статистично значущі відмінності між групами за строками стаціонарного лікування. Середній строк стаціонарного лікування хворих основної групи становив $(15,8 \pm 1,3)$ доби, порівняльної - $(14,5 \pm 1,5)$ доби ( $\mathrm{p}=0,002)$. Отже, використовуючи РМКВГМ, ми скоротили строки стаціонарного лікування хворих у середньому на 1,3 доби (95\% ВI 0,6 доби - 1,9 доби).

Повний некроз клаптя після його пересадки розвинувся у 2 (6,5\%) хворих основної групи. Часткового та крайового некрозу клаптів у пацієнтів даної групи не спостерігали. Крайовий некроз дистальної частини клаптя розвинувся у 3 (7,9\%) хворих порівняльної групи. Тотального та часткового некрозу клаптів у пацієнтів даної групи не спостерігали. Таким чином, частота розвитку ускладнень після пересадки клаптів у пацієнтів основної групи становила 6,5\%, у пацієнтів порівняльної групи - 7,9\% (p=0,81).

Розходження країв післяопераційної рани та формування оростом не спостерігали в обох групах хворих. Вірогідно, це пояснюється тим, що всі включені в дослідження пацієнти не отримували променевої або хіміопроменевої терапії перед оперативним втручанням. У 3 $(9,7 \%)$ хворих основної групи утворилися слинні нориці, у 2 (6,5\%) - гематома в ділянці післяопераційної рани. У порівняльній групі у 1 (2,6\%) пацієнта утворилася слинна нориця, у 1 (2,6\%) - гематома, а у 1 (2,6\%) виникли інфекційні ускладнення. Загалом частота післяопераційних ускладнень у пацієнтів основної групи становила 16,2\%, у пацієнтів порівняльної групи - 7,8\% (p=0,49).

Статистично значущих відмінностей за всіма показниками функціонального статусу (табл. 1) між групами хворих через 6 та 12 міс після оперативного лікування не виявлено ( $\mathrm{p}>0,05)$.
Статистично значущих відмінностей за всіма показниками якості життя (табл. 2) між групами хворих через 6 та 12 міс після оперативного лікування так само не виявлено $(\mathrm{p}>0,05)$.

\section{Обговорення}

В останні роки відновився інтерес до використання регіонарних клаптів для заміщення післяопераційних дефектів ротової порожнини. W. Li i співавтори вперше порівняли результати застосування ВПКП і стандартного регіонарного клаптя великого грудного м'яза для заміщення дефектів язика. Якість життя оцінювали за опитувальником Вашингтонського університету UW-QOL. Достовірних відмінностей між порівнюваними групами за показниками болю, активності, відпочинку, ковтання, жування, мовлення, смаку, слини, настрою, занепокоєння та загальної якості життя дослідники не виявили, проте встановили статистично значущі відмінності за показниками зовнішнього вигляду та функції плеча. Вищі значення показника зовнішнього вигляду констатували у пацієнтів, яким для реконструкції язика використовували регіонарний клапоть великого грудного м'яза. Автори пояснили це тим, що рубець на передній стінці грудної клітки на відміну від рубця передпліччя прихований одягом i пацієнти його легше сприймають. Показник функції плеча був вищий у групі пацієнтів, яким використали ВПКП. Пересічення великого грудного м'яза під час забору клаптя призвело до зменшення діапазону рухів плеча та відповідно до зниження показника функції плеча. Автори ще зазначили, що тривалість оперативного втручання у разі застосування ВПКП була достовірно більшою [11]. Нами також встановлено достовірно більшу тривалість оперативного втручання у разі використання ВПКП. Це пов'язано з додатковим часом, необхідним для підготовки донорських судин, накладання мікросудинних анастомозів та виконання аутодермопластики донорської ділянки.

У нашому дослідженні показник зовнішнього вигляду через 12 міс після хірургічного лікування в основній групі становив $(66,7 \pm 12) \%$, у порівняльній - $(69,2 \pm 10,8) \%$ $(p=0,43)$. Нами також не встановлено статистично значущих відмінностей між групами за показником функції плеча через 12 міс після хірургічного лікування: в основній групі він становив (70,4 \pm 16$) \%$, у контрольній - (70,7 $\pm 20,2) \%(p=0,85)$. За показниками болю, активності, відпочинку, ковтання, жування, мовлення, смаку, слини, настрою, занепокоєння та загальної якості життя групи були порівнянними. На нашу думку, модифікація клаптя зі збереженням ключичної та грудинно-ребрової частин

\begin{tabular}{|c|c|c|c|c|c|c|}
\hline \multirow{3}{*}{$\begin{array}{c}\text { Показники } \\
\text { функціонального статусу } \\
\text { за шкалою PSS - HN }\end{array}$} & \multicolumn{4}{|c|}{ Групи пацієнтів } & \multirow{2}{*}{\multicolumn{2}{|c|}{$\mathrm{p}$}} \\
\hline & \multicolumn{2}{|c|}{ основна } & \multicolumn{2}{|c|}{ порівняльна } & & \\
\hline & $\begin{array}{c}\text { через } 6 \text { міс } \\
(n=31)\end{array}$ & $\begin{array}{c}\text { через } 12 \text { міс } \\
(n=24)\end{array}$ & $\begin{array}{c}\text { через } 6 \text { міс } \\
(n=38)\end{array}$ & $\begin{array}{c}\text { через } 12 \text { міс } \\
(n=30)\end{array}$ & через 6 міс & через 12 міс \\
\hline Повноцінність дієти & $61,0 \pm 9,4$ & $60,4 \pm 7,5$ & $58,7 \pm 9,6$ & $60,3 \pm 10,3$ & 0,29 & 0,76 \\
\hline Харчування на людях & $64,5 \pm 12,5$ & $65,6 \pm 12,4$ & $65,1 \pm 12,4$ & $67,5 \pm 11,7$ & 0,84 & 0,57 \\
\hline Зрозумілість мовлення & $66,1 \pm 12,2$ & $64,5 \pm 12,6$ & $62,5 \pm 12,7$ & $64,2 \pm 12,6$ & 0,24 & 0,90 \\
\hline
\end{tabular}




\begin{tabular}{|c|c|c|c|c|c|c|}
\hline \multirow{3}{*}{$\begin{array}{l}\text { Показники якості життя } \\
\text { за опитувальником } \\
\text { UW-QOL v4 }\end{array}$} & \multicolumn{4}{|c|}{ Групи пацієнтів } & \multirow{2}{*}{\multicolumn{2}{|c|}{$\mathrm{p}$}} \\
\hline & \multicolumn{2}{|c|}{ основна } & \multicolumn{2}{|c|}{ порівняльна } & & \\
\hline & $\begin{array}{c}\text { через } 6 \text { міс } \\
(n=31)\end{array}$ & $\begin{array}{c}\text { через } 12 \text { міс } \\
(n=24)\end{array}$ & $\begin{array}{c}\text { через } 6 \text { міс } \\
(n=38)\end{array}$ & $\begin{array}{c}\text { через } 12 \text { міс } \\
(n=30)\end{array}$ & через 6 міс & через 12 міс \\
\hline Біль & $72,6 \pm 14,9$ & $76 \pm 13,8$ & $73 \pm 14,7$ & $75 \pm 11,4$ & 0,9 & 0,76 \\
\hline Зовнішній вигляд & $68,5 \pm 14,4$ & $66,7 \pm 12$ & $72,4 \pm 12,7$ & $69,2 \pm 10,8$ & 0,23 & 0,43 \\
\hline Активність & $71 \pm 14,6$ & $75 \pm 12,8$ & $71,7 \pm 14,4$ & $72,5 \pm 12$ & 0,83 & 0,48 \\
\hline Відпочинок & $68,5 \pm 11,1$ & $70,8 \pm 9,5$ & $70,4 \pm 9,8$ & $72,5 \pm 7,6$ & 0,47 & 0,5 \\
\hline Ковтання & $60,6 \pm 23,9$ & $60 \pm 21,7$ & $59,2 \pm 24,8$ & $58,5 \pm 22,1$ & 0,82 & 0,8 \\
\hline Жування & $48,4 \pm 20,3$ & $47,9 \pm 10,2$ & $50 \pm 20,1$ & $48,3 \pm 9,1$ & 0,75 & 0,9 \\
\hline Мовлення & $57,1 \pm 19$ & $58,3 \pm 18,6$ & $59,5 \pm 17,9$ & $60,7 \pm 17,2$ & 0,6 & 0,64 \\
\hline Функція плеча & $73,2 \pm 16,6$ & $70,4 \pm 16$ & $73,4 \pm 15,6$ & $70,7 \pm 20,2$ & 0,99 & 0,85 \\
\hline Смак & $53,2 \pm 20,1$ & $65 \pm 13,5$ & $51,1 \pm 20,2$ & $64,7 \pm 13,8$ & 0,66 & 0,93 \\
\hline Слина & $47,7 \pm 24,9$ & $60 \pm 17,7$ & $45,8 \pm 24,9$ & $60,7 \pm 17,2$ & 0,74 & 0,89 \\
\hline Настрій & $70,2 \pm 18,7$ & $68,8 \pm 13,3$ & $69,1 \pm 18,8$ & $71,7 \pm 15,7$ & 0,74 & 0,52 \\
\hline Занепокоєння & $69 \pm 15,8$ & $67,9 \pm 13,2$ & $70 \pm 15,1$ & $70,7 \pm 10,8$ & 0,81 & 0,45 \\
\hline \multicolumn{7}{|l|}{ Загальні запитання } \\
\hline A & $50,8 \pm 12$ & $49 \pm 11,6$ & $50,7 \pm 12,3$ & $52,5 \pm 13,7$ & 0,96 & 0,32 \\
\hline B & $55,5 \pm 8,5$ & $56,7 \pm 7,6$ & $54,7 \pm 8,9$ & $55,3 \pm 8,6$ & 0,73 & 0,56 \\
\hline C & $59,4 \pm 12,1$ & $59,2 \pm 9,3$ & $59,5 \pm 12,7$ & $59,3 \pm 14,4$ & 0,97 & 0,99 \\
\hline $\begin{array}{l}\text { A - За міс } \\
\text { В - Як би } \\
\text { C-Загалt }\end{array}$ & \multicolumn{6}{|c|}{$\begin{array}{l}\text { А - За місяць до того, як у Вас виявили рак, як би Ви оцінили стан свого здоров'я? } \\
\text { В - Як би Ви оцінили стан свого здоров'я протягом останніх } 7 \text { днів? } \\
\text { С-Загальна якість життя протягом останніх } 7 \text { днів. }\end{array}$} \\
\hline
\end{tabular}

великого грудного м'яза під час його забору дала змогу мінімізувати функціональні порушення в донорській ділянці та отримати показник функції плеча, порівнянний 3 відповідним показником після використання ВПКП. Про незначні функціональні порушення та добрий косметичний результат у донорській ділянці у разі збереження частини великого грудного м'яза повідомили M. Liu і співавтори [9]. Крім того, модифікація клаптя з селективним виділенням судинної «ніжки» дає змогу уникнути прив'язки реконструйованого язика до м'язової ніжки клаптя та досягти порівнянних між групами показників функціональної реабілітації.

Даних щодо порівняння строків стаціонарного лікування та частоти ускладнень у донорській ділянці у разі застосування РМКВГМ та ВПКП для закриття субтотальних дефектів язика дотепер у літературі немає. У нашому дослідженні показано, що використання РМКВГМ дає змогу достовірно скоротити тривалість стаціонарного лікування хворих. Частота утворення слинних нориць у хворих порівняльної групи була на 7,1\% нижчою, ніж у пацієнтів основної групи, що, ймовірно, вплинуло на строки стаціонарного лікування. На нашу думку, зменшення частоти утворення слинних нориць у хворих порівняльної групи пояснюється більшим заповненням «мертвих просторів» дна ротової порожнини м'язовою частиною грудного клаптя, ніж шкірно-фасціальним променевим клаптем передпліччя.

Перспективним напрямком подальших досліджень є порівняння результатів усунення субтотальних дефектів язика з використанням РМКВГМ та вільного перфорантного передньо-латерального клаптя стегна.

\section{Висновки}

1. РМКВГМ може бути першим вибором у разі заміщення субтотальних дефектів язика.

2. Застосування РМКВГМ для усунення субтотальних дефектів язика достовірно скорочує тривалість оперативного втручання та стаціонарного лікування у порівнянні із застосуванням ВПКП.

3. Не встановлено статистично значущих відмінностей за частотою розвитку ускладнень після пересадки клаптів, післяопераційних ускладнень, функціональним статусом та якістю життя між групами хворих, яким субтотальні дефекти язика заміщали РМКВГМ та ВПКП.

\section{Підтвердження \\ Фінансування}

Це дослідження є фрагментом планової НДР. Фінансування за рахунок держбюджету.

\section{Інформація про внесок кожного учасника}

Кравець О. В. - концепція, дизайн дослідження, збір і обробка матеріалів, написання тексту; Копчак А. В. - концепція і дизайн дослідження; Хлинін О. В. - збір і обробка матеріалів; Буртин О. В. - обробка матеріалів, аналіз отриманих даних; Гур'янов В. Г. -аналіз отриманих даних. Всі автори прочитали і схвалили остаточний варіант рукопису.

\section{Конфлікт інтересів}

Автори інформують про відсутність потенційних та явних конфліктів інтересів, пов'язаних з рукописом.

\section{Згода на публікацію}

Всі автори дали згоду на публікацію цього рукопису.

Всі процедури проведеного дослідження затверджені комісією з питань етики Національного інституту раку. 


\section{References}

1. Spiotto MT, Jefferson G, Wenig B, Markiewicz M, Weichselbaum RR, Koshy M. Differences in survival with surgery and postoperative radiotherapy compared with definitive chemoradiotherapy for oral cavity cancer. A national cancer database analysis. JAMA Otolaryngol Head Neck Surg. 2017 Jul 1;143(7):691-9. https://doi.org/10.1001/jamaoto. 2017.0012

2. Manrique OJ, Leland HA, Langevin CJ, Wong A, Carey JN, Ciudad P, et al. Optimizing outcomes following total and subtotal tongue reconstruction: a systematic review of the contemporary literature. J Reconstr Microsurg. 2017 Feb;33(2):103-11. https://doi. org/10.1055/s-0036-1593772. Epub 2016 Oct 31.

3. Takatsu J, Hanai N, Suzuki H, Yoshida M, Tanaka Y, Tanaka S, et al. Phonologic and acoustic analysis of speech following glossectomy and the effect rehabilitation of speech outcomes. J Oral Maxillofac Surg. 2017 Jul;75(7):1530-41. https://doi.org/10.1016/j.joms.2016.12.004. Epub 2016 Dec 11.

4. Ozkan O, Ozkan O, Derin AT, Bektas G, Cinpolat A, Duymaz A, et al. True functional reconstruction of total or subtotal glossectomy defects using a chimeric anterolateral thigh flap with both sensorial and motor innervation. Ann Plast Surg. 2015 May;74(5):557-64. https://doi. org/10.1097/SAP.0b013e3182a6add7.

5. Yuan Y, Zhang P, He W, Li W. Comparison of oral function: free anterolateral thigh perforator flaps versus vascularized free forearm flap for reconstruction in patients undergoing glossectomy. J Oral Maxillofac Surg. 2016 Jul;74(7):1500.e1-6. https://doi.org/10.1016/j.joms.2016.03.039.
6. Vega C, León X, Cervelli D, Pons G, López S, Fernández M, et al. Total or subtotal glossectomy with microsurgical reconstruction: functional and oncological results. Microsurgery. 2011 Oct;31(7):517-23. https:// doi.org/10. 1002/micr.20922.

7. Patel UA, Hartig GK, Hanasono MM, Lin DT, Richmon JD. Locoregional flaps for oral cavity reconstruction: a review of modern options. Otolaryngol Head Neck Surg. 2017 Aug;157(2):201-9. https://doi. org/10.1177/0194599817700582.

8. Mahieu R, Colletti G, Bonomo P, Parrinello G, Iavarone A, Dolivet G, et al. Head and neck reconstruction with pedicled flaps in the free flap era. Acta Otorhinolaryngol Ital Acta Otorhinolaryngol Ital. 2016 Dec; 36(6): 459-68. https://doi.org/10.14639/0392-100X-1153

9. Liu M, Liu W, Yang X, Guo H, Peng H. Pectoralis major musculocutaneous flap for head and neck defects in the era of free flaps: harvesting technique and indications. Sci Rep. 2017 Apr 7;7:46256. https://doi org/10.1038/srep46256.

10. Bussu F, Gallus R, Navach V, Bruschini R, Tagliabue M, Almadori $\mathrm{G}$, et al. Contemporary role of pectoralis major regional flaps in head and neck surgery. Acta Otorhinolaryngol Ital. 2014 Oct;34(5):327-41. [PMID: 25709148].

11. Li W, Zhang P, Li R, Liu Y, Kan Q. Radial free forearm flap versus pectoralis major pedicled flap for reconstruction in patients with tongue cancer: Assessment quality of life. Med Oral Patol Oral Cir Bucal. 2016 Nov 1;21(6):e737-e742. https://doi.org/10.4317/medoral.21274.

Надійшла 19.12.2018 